\title{
IN SEARCH OF A CONTEMPORARY DEFINITION OF MEANINGFUL ENGAGEMENT: A SYSTEMATIC LITERATURE REVIEW
}

\author{
Tania Kate Hobson*, Anneke Fitzgerald, Katrina Radford \\ Griffith University, Queensland Australia
}

Correspondence: tania.hobson@griffithuni.edu.au

\begin{abstract}
Consumer engagement is emerging as an important trend in a contemporary health care environment. Yet, a universal definition of meaningful consumer engagement has not been determined. This paper presents our systematic literature review findings, which intended to consolidate the definition of consumer engagement (or related terms) in the context of health care to date to arrive at a definition for meaningful consumer engagement in healthcare. Literature searches were performed in MEDLINE, CINAHL, Embase and PsychINFO in June 2021. Using a combination of medical subject headings (MeSH) terms, Emtree search headings and free text words, a total of 82 records were identified. After reviewing in line with PRISMA methodology, 23 articles were considered relevant to the development of the definition of consumer engagement. The methodology of these papers was analysed using the revised Mixed Methods Appraisal Tool (MMAT) (2018). A total of 13 of these papers were then further analysed for a definition of meaningful consumer engagement or characteristics of consumer engagement. None of the definitions found comprehensively defined meaningful consumer engagement but instead, five described meaningful consumer engagement. Therefore, a new definition of meaningful consumer engagement is proposed, which is based upon the synthesis of the characteristics of meaningful consumer engagement and person-centred care. This new definition speaks to what is it means to be consumers of health care rather than patients and acknowledged the importance of the reciprocity of the exchange relationship of 'consumers', the importance of leadership, and the emerging evidence around diversity and inclusion trust and partnership which requires active involvement and participation.
\end{abstract}

\section{KEYWORDS}

consumer engagement, meaningful, healthcare, person-centred care, definition, quality assessment, characteristics, qualitative research, systematic literature, quality appraisal

\section{INTRODUCTION}

Consumer engagement has emerged as an important trend in contemporary health services. [1] By providing unique insights and perspectives, consumers help organisations better understand their needs and enhance the value of healthcare solutions and systems being developed. [1, 2] There is a growing body of evidence which suggests that engagement of consumers and their families leads to more empowered patients and more engaged patients have better perceived health outcomes 
[3, 4] and improved quality of care. [5] Thus, an understanding of how to engage consumers effectively is needed.

Recently, Majid [6] explored the concept of tokenism in the context of consumer engagement and found that there is a lack of clarity regarding the meaning of and implications for tokenism on consumer engagement. As part of the study, the four dimensions of tokenism: unequal power, limited impact, ulterior motives, and opposite of meaningful patient engagement were reviewed in the context of levels of engagement outlined in the International Association of the Public Participation spectrum. [16] Importantly, this review suggests that there are two gradations of tokenism and whilst tokenism represents unequal power relationships in favour of health care professionals, this may lead to either limited or no meaningful change or change that is primarily aligned with the personal and professional goals of clinicians, managers, and decision-makers. [6]

Carmen and colleagues [7] acknowledge consumer engagement spans across a continuum of care for patients and families and across funding and policy jurisdictions. The engagement continuum itself can range from consultation to partnership as well as shared leadership, including decision-making authority. [7] At one end of the continuum, consumers are involved in their health care but have limited power or decision-making authority. [7] At the other end of the continuum, engagement is characterised by shared power and responsibility, with consumers considered active partners in shaping agendas and making health care decisions. [7] Consumer engagement can occur at multiple levels throughout the health care system, from a direct care setting right through to incorporating patient engagement into organisational design, governance, and policy making. [7] In addition, the level of consumer engagement in health care organisations is determined by three things: first, the level of participation that a health care organisation will support, second, the level that is advocated for by consumers, and third, the confidence, knowledge, and skill levels of consumers and their families. [8] Furthermore, Halabi [9] who also developed a conceptual framework the phases of "patient participation" found the common goal across the framework was the inclusion of the patient in the healthcare system.

According to Higgins and colleagues' [8] engaged patient/ consumer-professional partnerships are needed across all levels in healthcare organisations. Yet the basis of their proposed framework uses loosely defined terms such as consumer, community and engagement, that are often not agreed upon definitions in the literature. For example, Evans [10] found that 'community' has been used to describe patients, consumers, citizens, clients, service users and carers (in relation to patients) amongst many other terms. Further, the use of the term engagement varies from the 'principles' of engagement, including patient or consumer participation or choice to the 'practice' of engagement, including examples such as patient or consumer surveys, patient networks, complaints mechanisms, consumer councils or citizens juries. [2]

Consequently, there is variation in the definition of consumer engagement. The variation in definitions and the inter-changing of terminology could, in part, be reflective of the spectrum of continuum of engagement that occurs in health care, and, therefore, a comprehensive and inclusive definition of "consumer engagement" needs to be agreed upon.

This paper argues that the currently used definitions of consumer engagement do not indicate that meaningful engagement and exchanges have occurred between patients and their families and health care providers. A meaningful social exchange relationship that is required between consumers and their families and health care providers ranges from undertaking relatively simple tasks (such as the creation of a brochure) and co-designing complex care issues, such as changes to a model of care.

The required social exchange relationships for successful and meaningful engagement between an organisation and its consumers are theorised within Social Exchange Theory (SET), which focuses attention on the relations between actors and the factors that explain the emergence, maintenance and termination of exchange. The exchange relationship can be viewed strictly as dyadic [11] or can be viewed as connected to form networks of exchanges. [12,13, 14] This exchange relationship is essential when engaging with consumers.

\section{CONCEPTUAL FRAMEWORK}

Social Exchange Theory (SET) weaves together disciplines such as anthropology [15], social psychology [16], and sociology. [17] Blau [17] states that SET involves a series of social and economic interactions and exchanges that generate obligations to reciprocate which, in turn, engenders feelings of personal obligations, gratitude, and 
trust. It is worth noting that social exchange differs from an economic exchange in terms of resources exchanged, type and strength of obligations, reciprocity, and the quality of the relationship developed over time. [18] Further, whilst economic exchange involves defined provisions of the interactions between parties and is predominated by extrinsic rewards particularly material rewards, social exchange is characterised by indeterminate personal obligations and trust as well as both intrinsic and extrinsic rewards. [17]

The basic assumption of exchange theory is that individuals establish and continue social relations on the basis of their expectations that such relations will be mutually advantageous. [17] In the context of consumer representation, individual consumers establish and continue social relations with each other and with employees in health service organisations on the basis that that such relations are mutually advantageous. [17]

The aim of this systematic literature review is to analyse the existing definitions of consumer engagement in order to best define 'meaningful consumer engagement' in the health care context. 'Meaningfulness', in part, can be derived from the exchange relationship. The development of a single definition of 'meaningful consumer engagement' will give rise to a shared understanding of the depth and breadth of consumer engagement for researchers, academics, policy makers and clinicians which, in turn, has the potential to improve health and health outcomes for patients and their families.

\section{METHODS}

The study was conducted in accordance with the Preferred Reporting Items for Systematic Reviews and Meta-Analyses (PRISMA) statement. [19] PRISMA is an evidence-based minimum set of items for reporting in systematic reviews and meta-analyses. The methods of the analysis and inclusion for this Systematic Literature Review were specified in a protocol. The PRISMA statement consists of both the 27-item checklist and the four-phase flow chart. [19] (see Figure 2) The search strategy and study selection used in the systematic literature review is detailed below. A systematic review was selected as the explicit type of review typology, given such a review is aligned to the principal purpose of the review being to summarise what is known as well as provide recommendations for both practice and future research. [20]

\section{SEARCH STRATEGY AND STUDY SELECTION}

A comprehensive electronic database search was conducted by one author on the 12th January 2020. The literature search was conducted in Literature Analysis and Retrieval System (MEDLINE), Cumulative Index to Allied Health Research (CINAHL) Embase and PsychINFO for primary qualitative, quantitative, or mixed methods studies. These two databases were recommended for use by the librarian and also form the basis of similar systematic literature reviews on similar topics. [21The search terms were initially determined through reviewing a selection of key papers and an initial scoping search. One researcher ran the combination of these strategies in the appropriate databases. The key search terms are outlined in Appendices 1,2, 3 and 4. Given the variable terms used to describe the same or similar topic, a broad search strategy with a high sensitivity was used. The search strategy included a combination of medical subject headings (MeSH), embase subject headings (emtree) and free text words.

\section{ELIGIBILITY CRITERIA}

Two reviewers screened titles and abstracts of all articles that met the search strategy order to determine studies eligible for inclusion). A third reviewer was available if consensus was unable to be researched however this was not required. For convenience, articles had to be published in English and be available in an electronic format. Other formats and languages were excluded. Studies were considered from the year of inception of the online database to June2021 (see Table 1). If insufficient information was available in the title and abstract of an article, a full- text evaluation was undertaken. Following this, the same reviewer assessed the full text of potentially relevant non-duplicated articles and conference proceeding or poster presentations.

The articles that met the inclusion criteria were selected and entered to the final analysis. These studies contained a definition of consumer engagement or a related term. That is, they were selected according to the review objectives and Population, Intervention, Comparison, Outcomes, and Study design (PICOS) criteria (see Table 1). 
TABLE 1: PICOS CRITERIA FOR THE STUDY

\begin{tabular}{|c|c|}
\hline CRITERIA & INCLUSION \\
\hline Population & The population related to consumer engagement in health care \\
\hline Intervention & $\begin{array}{l}\text { Definition of meaningful consumer engagement or related term, or characteristics } \\
\text { of meaningful engagement or related term }\end{array}$ \\
\hline Comparator & $\begin{array}{l}\text { No definition of meaningful consumer engagement or related term or } \\
\text { characteristics of meaningful engagement or related term }\end{array}$ \\
\hline Outcomes & Contemporary definition of meaningful consumer engagement \\
\hline Study design & $\begin{array}{l}\text { The systematic literature review focused on a definition of meaningful consumer } \\
\text { engagement in health care. } \\
\text { Articles had to be published in English and be available in an electronic format via } \\
\text { the electronic databases or the internet. }\end{array}$ \\
\hline
\end{tabular}

FIGURE 1. PRISMA FLOW CHART: SYSTEMATIC LITERATURE REVIEW

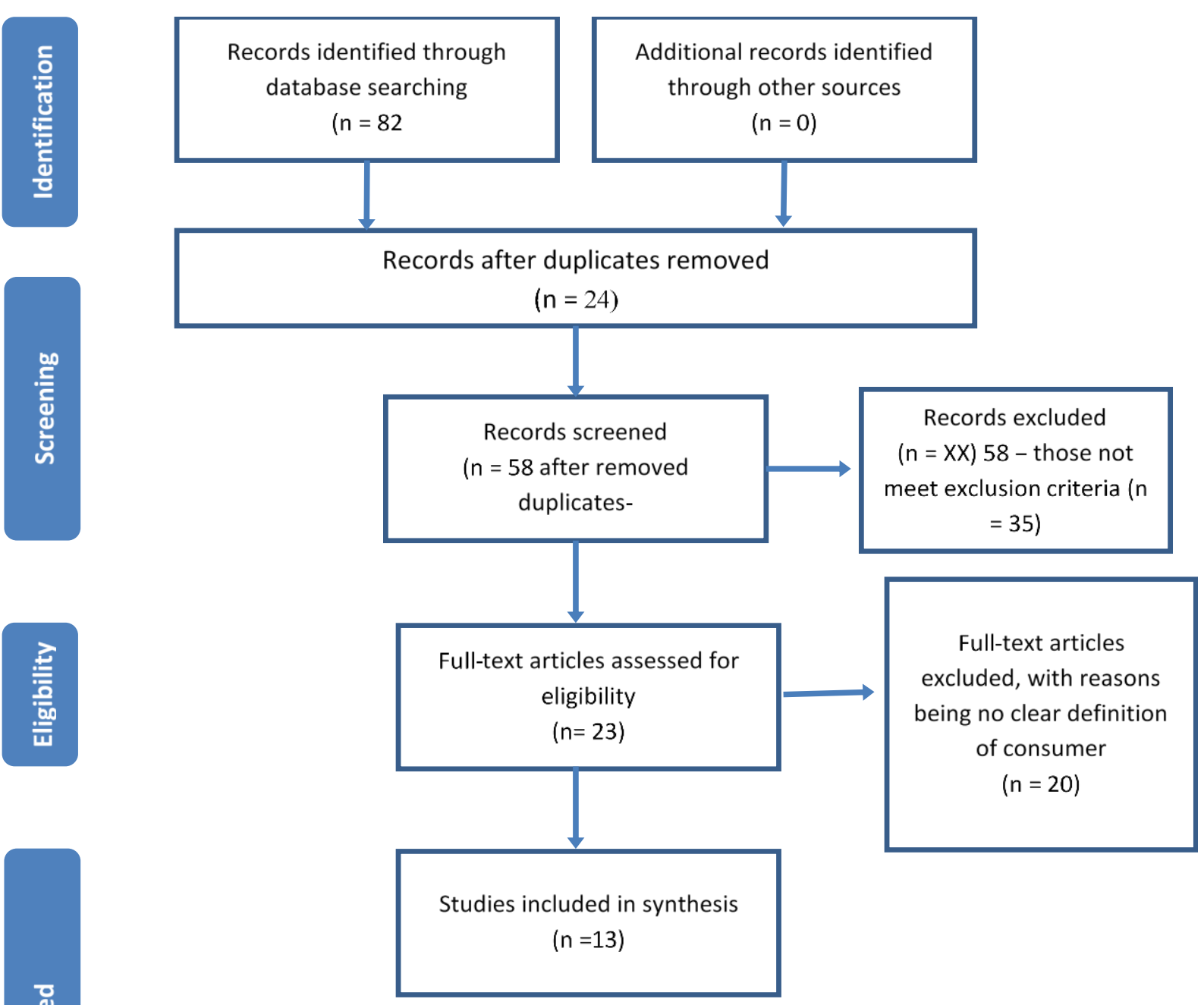




\section{QUALITY ASSESSMENT}

The revised Mixed Methods Appraisal Tool (MMAT) [22] was the quality assessment tool selected given it assesses the quality of qualitative, quantitative, and mixed methods studies. Further, it focuses on methodological criteria and includes five core quality criteria for each of the following five categories of study designs: (a) qualitative, (b) randomised controlled, (c) nonrandomized, (d) quantitative descriptive, and (e) mixed methods. Majid and Vanstone [23] suggested that the decision of which appraisal tool to use depends on the objectives of the evidence synthesis, the expertise of the researchers, and the time and resources available. A series of 23 articles were reviewed using MMAT. Of these, 13 articles meet both screening criteria and were subsequently brought forward for further analysis (see Table 2). Seven of the articles (see Table 3) did not meet the screening criteria for the MMAT evaluation. That is, these seven articles did not clearly articulate a research question and the data collection method did not allow for the answering of the research question.

\section{RESULTS}

This review summarises the findings from 13 articles that focused on either, a definition of meaningful consumer engagement (related term) or discussed the characteristics of meaningful consumer engagement (or related terms) (see Table 3). The scope of the review related to a definition at a service or organisational level or associated characteristics that could be used to form part of the definition. Of the 82 articles, 13 articles made it through the Quality Assessment using MMAT, a total of 5 articles provided a definition of meaningful consumer engagement or a similar term or characteristics of consumer engagement at a service or organisational level. Table 3 summarises the range of definitions or characteristics of consumer engagement.

By way of classification the definitions were compared to each other using the continuum of engagement outlined by Carmen and colleagues [7] and depicted in Figure 1. The definitions are also categorised as either relating to patients, families, staff or health care organisations (see Table 4). The definitions are categorised according to their depiction of direct care, organizational design and governance and/or policy making. Given the number of articles that relate to research that formed part of the review, 'research' was added as a category which was not originally detailed by Carmen and colleagues. [7] The papers written by Phillips et al [24] and Westlake, Ekman, Britten and Lloyd [25] were focuses on individual patient and clinician partnerships but were seen as applicable at a service level and organisational level engagement. More specifically, Phillips et al [24], who undertook semistructured individual interviews to address the knowledge gap relating to the evidence around effective engagement with consumers from ethnic minority backgrounds found that recognising diversity within communities and individuals in those communities was as pivotal to effective engagement. Further, Westlake and colleagues [25], who conducted a secondary analysis of qualitative data in developing a framework which identified contextual factors and mechanisms likely to contribute to effective engagement (see Table 3).

\section{TABLE3. CLASSIFICATION OF DEFINITIONS ACCORDING TO ASPECTS OF ENGAGEMENT AND STAKEHOLDERS CONSIDERED}

\begin{tabular}{|l|l|l|}
\hline ARTICLE & $\begin{array}{l}\text { ASPECTS OF ENGAGEMENT } \\
\text { CONSIDERED }\end{array}$ & STAKEHOLDERS CONSIDERED \\
\hline Westlake et al. [25] & Direct Care & $\begin{array}{l}\text { Patients and public } \\
\text { Individual }\end{array}$ \\
\hline Majid and Gagliardi [26] & $\begin{array}{l}\text { Organisational Design and } \\
\text { Governance } \\
\text { Policy making }\end{array}$ & $\begin{array}{l}\text { Patients and public } \\
\text { Individuals } \\
\text { Health care organisations }\end{array}$ \\
\hline Pinsoncult et al [27] & Direct Care & $\begin{array}{l}\text { Patients and public } \\
\text { Individual }\end{array}$ \\
\hline Warren et al [28] & Direct Care & $\begin{array}{l}\text { Patients and public } \\
\text { Individuals }\end{array}$ \\
\hline
\end{tabular}




\begin{tabular}{|l|l|l|}
\hline & & Other - research \\
\hline Phillips et al 24] & Direct Care & $\begin{array}{l}\text { Patients and public } \\
\text { Individuals }\end{array}$ \\
\hline Newell and Jordan [29] & Direct Care & Individuals \\
\hline Kane et al [30] & Direct Care & Individuals \\
\hline DeCamp et al [31] & Direct Care & Individuals \\
\hline Sapir et al [32] & Direct Care & Individuals \\
\hline Sloan and Knowles [(33] & Direct Care & Individuals \\
\hline Harrison et al [34] & $\begin{array}{l}\text { Direct Care } \\
\text { Organisational Design and } \\
\text { Governance } \\
\text { Policy making }\end{array}$ & $\begin{array}{l}\text { Patients and public } \\
\text { Individuals } \\
\text { Health care organisations }\end{array}$ \\
\hline Perfetto et al [35] & $\begin{array}{l}\text { Direct Care } \\
\text { Organisational Design and } \\
\text { Governance } \\
\text { Policy making }\end{array}$ & $\begin{array}{l}\text { Patients and public } \\
\text { Individuals } \\
\text { Health h care organisation }\end{array}$ \\
\hline Needham et al [36] & $\begin{array}{l}\text { Organisational Design and } \\
\text { Governance }\end{array}$ & Other - research \\
\hline
\end{tabular}

None of the five articles (Westlake, Ekman, Britten, and Lloyd or a similar term but all spoke to characteristics of [26], Majid and Gagliardi [27]; Phillip et al. [24], Perfetto, meaningful consumer engagement in health care (see Oehrlein, Boutin, Reid, and Gascho. [35], Harrison et al. [34]), Table 4). provided a definition of meaningful consumer engagement

\section{TABLE 4. CHARACTERISTICS OF MEANINGFUL CONSUMER}

\begin{tabular}{|l|l|}
\hline ARTICLE & CHARACTERISTICS \\
\hline Majid and Gagliardi [26] & Collaboration, \\
Co-operation, \\
Co-production, \\
Active involvement, \\
Partnership, and \\
Consumer peer leadership \\
\hline Westlake et al [25] & $\begin{array}{l}\text { Care partnership } \\
\text { Trust }\end{array}$ \\
\hline Phillip et al [24] & Patient's sense of candidacy \\
& Patient-clinician partnership, \\
& Benefits, \\
\hline
\end{tabular}




\begin{tabular}{|l|l|}
\hline & Applicability \\
\hline Perfetto et al [35] & Partnership, \\
& Transparency, \\
Inclusiveness, \\
Diversity, \\
Outcomes \\
Data sources
\end{tabular}

There are commonalities and differences between the five articles in their description of characteristics of meaningful consumer engagement. While all articles stress the partnerships between consumers and health care providers. Some researchers focus on the behaviours or actions that organisations and consumers can take (e.g., Westlake et al [25], Majid \& Gagliardi [26]), with researchers, such as Majid and Gagliardi [26] discuss the need for active involvement. Others such as, Harrison et al.[34] and Perfetto et al. [35] stress the importance of diversity. A number of researchers spoke to the importance of trust and respect. $[25,34]$ Thus, trust, respect, partnerships and active involvement within organisations were central to describing meaningful consumer engagement in the articles reviewed.

Upon reviewing the characteristics that pertain to meaningful consumer engagement, it was found that enabling consumers to take on leadership roles within an organisation were identified as central to meaningful engagement of consumers. For example, patients as consumer/peer leaders were recognized as professionals who managed administrative and organisational activities and were compensated for their work [ Majid \& Gagliardi, 26]. In this way, consumer/peer leadership appeared to be a more reputable and legitimized form of consumer engagement accepted within organisations for real change to occur. Perfetto et al. [34] also identified that the level of meaningfulness in consumer engagement could be categorised through a Rubric framework assessment map. This framework was proposed to include a self-assessment of the level of partnership, transparency, inclusiveness, diversity, outcomes, and data sources that were embedded within the organisation [26] Additionally, a patient's sense of candidacy was identified as an important characteristic identified by Westlake, and colleagues where consumes felt that there was a shared understanding of purpose, clarity of expectation and power sharing that existed to enable a true partnership with the organisation. [25]

\section{DISCUSSION}

This Systematic Literature Review was undertaken to determine if a definition of, or characteristics of, meaningful consumer engagement at a service organisational level exists within the literature in the health care context. Upon analysis and synthesis no existing definition was found to comprehensively describe meaningful consumer engagement within the health care context.

Thus, this paper presents a consolidated definition of meaningful consumer engagement, which encompasses the core characteristics identified in the literature. subsequently, meaningful consumer engagement is defined as, "the desire and capability of patients, families working in partnership with health care professionals and health care organisation, at various levels across the health care system to make improvements in the outcomes and experiences of care through actively involvement and participation that takes into consideration the establishment of trust, recognises the importance of clinical and patient leadership, and respects diversity and inclusiveness in all efforts. ".

The developed definition is significant, as it blends both the traditional characteristics of consumer engagement [24, 
25], 26] with the emerging concepts of patient leadership [26] and diversity and inclusion [34, 35], trust [25, 34] and partnerships. [ 24, 25, 34, 35] Importantly, the proposed definition focuses on mutual relationships and exchanges that exist between stakeholders to improve outcomes and experiences of care and emphasises the importance of social and mutual exchanges in this engagement activity. The proposed new definition also aligns with the far end of the continuum described in Figure 1, where meaningful engagement is characterised by shared power and responsibility and an active partnership between consumers and the health care organisation as highlighted by Carmen et al. [7] In addition, the proposed definition focuses on consumer engagement at the top two layers of the health care system depicted in Figure 1, namely organisational design and policy making.

Importantly, the definition emphasises collaborative partnerships between patients (and caregiver as defined by the patient) and health professionals as an essential ingredient of improved care and health. The collaborative and active partnerships arguably contribute to the meaningfulness of their definition. Further, it is reinforced by the concept of Social Exchange theory and importantly the norm of reciprocity. [45] That is, the high-quality relationships that can been generated by inter-dependent social exchanges are theoretically underpinned by the meaningfulness of the consumer engagement that can occur in health care.

\section{STRENGTHS AND LIMITATIONS}

It is clear that a consolidated definition of meaningful consumer engagement is needed in the literature that encompasses the core characteristics as well as the importance of meaningfulness.

Further, it is acknowledged that there is a variety of terminology used for the same or similar concepts relating to consumer engagement. As result of this, the concept of 'meaningful' in consumer engagement was imbued as part the review through the inclusion of synonyms of meaningfulness as search terms including active, genuine, optimal, effective, partnership, co-leadership, as part of the systematic literature review.

Further, some of the definitions or characteristics of meaningful consumer engagement or similar phrase may have been picked up due to the key words used within these articles. Therefore, while all care was taken to be inclusive, not all papers related to consumer engagement may have been identified within this systematic literature review. This is important because health policy increasingly demands organisations to meaningfully engage consumers in its practices and as such, understanding salient characteristics of consumer engagement as well as the significance of consumer engagement is essential to this aim. Thus, a review of the literature served to provide the opportunity to explore a definition or characterises of 'meaningful consumer engagement'.

The development of a single definition of 'meaningful consumer engagement' at each level of the engagement continuum allows for greater understanding of the depth and breadth of consumer engagement for researchers, academics, policy makers and clinicians which, in turn, has the potential to improve health and health outcomes for patients and their families. Future empirical evidence is needed to explore if the new definition accurately addresses the entire continuum of consumer engagement that exists in practice today. Another limitation of the methodological design was a sole reliance on a systematic literature review to determine the definition of engagement. Ideally in determining a definition or characteristics it is best practice to engage those involved in this process: patients, clinical and non-clinical professionals, and institutions.

Thus, is it clear that a consolidated definition of meaningful consumer engagement is needed in the literature that encompasses the core characteristics as well as the importance of meaningfulness. Further, it may be helpful for multiple definitions of meaningful consumer engagement be developed for clinician, researchers, and consumer alike to utilised based upon the context of an activity been undertaken along the engagement continuum. In addition, the proposed definition focuses on consumer engagement at all three layers of the health care system depicted in Figure 1, namely, direct care setting right through to organisational design and policy making.

\section{CONCLUSION}

Consumer engagement has emerged as an important trend in a contemporary health care environment. This paper reports the findings of a systematic literature review which aimed to consolidate the research to date to arrive at a definition or characteristics for meaningful consumer engagement at a service or organisational level. Lack of an existing definition of meaningful consumer engagement in health care at a service or organisation level does 
underpin the need for a consolidated definition of meaningful consumer that encompasses the core characteristics as well as the importance of meaningfulness. Further, it may be helpful for multiple definitions of meaningful consumer engagement be developed for clinician, researchers, and consumer alike to utilised based upon the context of an activity been undertaken along the engagement continuum.

Importantly, the development of a single definition of 'meaningful consumer engagement' gives rise to a shared

\section{References}

1. Frampton S, Guastello S. Putting Patients First: PatientCentered Care: More than the Sum of Its Parts. AJN. 2010; 110(9):49-53.

2. Australian Commission on Safety and Quality in Health Care. National Safety and Quality Health Service Standards (second edition) [Internet]. Sydney: Australian Commission on Safety and Quality in Health Care, 2017 [cited 2020 July 18]. 81 p. Available from: https://www.safetyandquality.gov.au/sites/default/file s/migrated/National-Safety-and-Quality-HealthService-Standards-second-edition

3. Doyle C, Lennox L, Bell D. A systematic review of evidence on the links between patient experience and clinical safety and effectiveness. BMJ Open, 2013 [cited 2021 July 15]; 3(1). Available from: 10.1136/bmjopen-2012-001570

4. Bloom B. Crossing the quality chasm: a new health system for the 21 st century. JAMA: The Journal of the American Medical Association. 2002 Feb 6;287(5):6467.

5. Barello S, Graffigna G, Vegni E. Patient engagement as an emerging challenge for healthcare services: mapping the literature. Nursing research and practice. 2012 Oct $31 ; 2012$ from:

https://doi.org/10.1177/2374373520925268

6. Majid U. The dimensions of tokenism in patient and family engagement: A concept analysis of the literature. J Patient Exp 2020 Dec;7(6):1610-20.

7. Carman KL, Dardess P, Maurer M, Sofaer S, Adams K, Bechtel $C$ et al. Patient and family engagement: a framework for understanding the elements and developing interventions and policies. Health Aff. 2013 Feb $1 ; 32(2): 223-31$. understand of the depth and breadth of consumer engagement across the continuum of engagement for researchers, academics, policy makers and clinicians, which, in turn, has the potential to improve health and health outcomes for patients and their families. Finally, a definition of meaningful consumer engagement that speaks to what is means to be consumers of health care rather than patients and acknowledges the importance of the reciprocity of the exchange relationship of 'consumers' of health care and staff in health care organisations is important.

8. Higgins T, Larson E, Schnall R. Unraveling the meaning of patient engagement: a concept analysis. Patient Educ Couns. 2017 Jan; 100(1):30-6.

9. Halabi IO, Scholtes B, Voz, B, Gillain, N, Durieux, N, Odero, A, et al. Bragard, I. "Patient participation" and related concepts: A scoping review on their dimensional composition. Patient Educ Couns. 2020; 103(1), 5-14.

10. Evans D, Pilkington $P, M c$ Eachran M. Rhetoric or reality? A systematic review of the impact of participatory approaches by UK public health units on health and social outcomes. Journal of Public Health. 2010 Sep 1;32(3):418-26.

11. Thibaut J, Kelley H. Social exchange theory. A first look at communication theory. 2008:196-205.

12. Cook KS, Emerson RM. Power, equity and commitment in exchange networks. Am Sociol Rev. 1978 Oct; 1:72139

13. Emerson, RM. Power-Dependence Relations. Am Sociol Rev. 1962 27:31- 40.

14. Molm LD, Cook KS. Social exchange and exchange networks. Sociological perspectives on social psychology. 1995;2(3):209-35.

15. Sahlins M. Stone age economics, London. Tavistock Publications. in Neanderthals. Proceedings of the National Academy of Sciences USA. 1974;108:87.

16. Gouldner AW. The norm of reciprocity: A preliminary statement. Am Sociol Rev. 1960 Apr 1:161-78.

17. Blau PM. (1964). Exchange and power in social life. New York: John Wiley and Sons.

18. Shore LM, Bommer WH, Rao AN, Seo J. Social and economic exchange in the employee-organization relationship: the moderating role of reciprocation 
wariness. Journal of Managerial Psychology. 2009 Nov 6.

19. Liberati A, Altman DG, Tetzlaff J, Mulrow C, Gøtzsche PC, loannidis JP, Clarke M, Devereaux PJ, Kleijnen J, Moher D. The PRISMA statement for reporting systematic reviews and meta-analyses of studies that evaluate health care interventions: explanation and elaboration. Clin Epidemiol. 2009 Oct; 62(10):1-34.

20. Grant, MJ. Booth, A. A typology of reviews: an analysis of 14 review types and associated methodologies. Health Info Libr J. 2009 26(2), 91-108.

21. Sarrami Foroushani P, Travaglia J, Eikli M, Braithwaite J. Consumer and community engagement: a review of the literature. 2012 Sydney: Centre for Clinical Governance Research, Australian Institute of Health Innovation, Faculty of Medicine, University of New South Wales, and the Agency for Clinical Innovation. New South Wales.

22. Hong QN, Fàbregues S, Bartlett G, Boardman F, Cargo M, Dagenais P, Gagnon MP, Griffiths F, Nicolau B, O'Cathain A, Rousseau MC. The Mixed Methods Appraisal Tool (MMAT) version 2018 for information professionals and researchers. Education for Information. 2018 Jan 1;34(4):285-91. Available at https://doi.org/10.3233/EFI-180221

23. Majid, U., \& Vanstone, M. (2018). Appraising qualitative research for evidence syntheses: a compendium of quality appraisal tools. Qua Health Res. 2018, 28(13), 2115-2131.

24. Phillips RL, Short A, Kenning A, Dugdale P, Nugus P, McGowan R et al. Achieving patient-centred care: the potential and challenge of the patient-asprofessional role. Health Expect. 2015, 18(6), 26162628. Available at https://doi.org/10.1111/hex.12234

25. Westlake, D, Ekman, I, Britten, N, Lloyd, H. Terms of engagement for working with patients in a personcentred partnership: A secondary analysis of qualitative data. Health Soc Care Community.2021;00:1-11. https://doi.org/10.1111/hsc.13406

26. Majid U, \& Gagliardi A. Clarifying the degrees, modes, and muddles of "meaningful" patient engagement in health services planning and designing. Patient Educ Couns. 2019 102(9), 1581-1589. Available at: https://doi.org/10.1016/j.pec.2019.04.006
27. Pinsoneault LT, Connors, ER, Jacobs, EA, \& Broeckling, J. Go Slow to Go Fast: Successful Engagement Strategies for Patient-Centered, Multi-Site Research, Involving Academic and Community-Based Organizations. J Gen Intern Med. 2019, 34(1), 125-131. Available at: https://doi.org/10.1007/s1 1606-018-4701$\underline{6}$

28. Warren NT, Gaudino Jr JA, Likumahuwa-Ackman S, Dickerson K, Robbins L, Norman K, Lind J, D Amato S, Foley P, Gold R, Baver V. Building meaningful patient engagement in research: case study from ADVANCE clinical data research network. Medical care. 2018 Oct; 56(10 Suppl 1): S58. Available at: https://doi.org/10.1097/MLR.0000000000000791

29. Newell S \& Jordan Z. The patient experience of patient-centered communication with nurses in the hospital setting: a qualitative systematic review protocol. JBI Database System Rev Implement Rep. 2015, 13(1), 76-87. Available at: https://doi.org/10.11124/jbisrir-2015-1072

30. Kane PM., Murtagh, FE, Ryan K, Mahon NG, McAdam B, McQuillan $R$ et al. The gap between policy and practice: a systematic review of patient-centred care interventions in chronic heart failure. Heart Fail Rev. 2015, 20(6), 673-687. Available at: https://doi.org/10.1007/s10741-015-9508-5

31. DeCamp, LR, Polk, S, Chrismer, MC, Giusti, F, Thompson, D A, Sibinga E. Health Care Engagement of Limited English Proficient Latino Families: Lessons Learned from Advisory Board Development. Prog Community Health Partnersh. 2015, 9(4), 521-530. Available at: https://doi.org/10.1353/cpr.2015.0068

32. Sapir T, Moreo KF, Greene LS, Simone LC, Carter JD, Mateka JJ, Hanania NA. Assessing patient and provider perceptions of factors associated with patient engagement in asthma care. Annals of the American Thoracic Society. 2017 May; 14(5):659-66. Available at: https://doi.org/10.1513/AnnalsATS.201608-6020C

33. Sloan, AG, Knowles A. Patient engagement: qualitative narratives illustrate patient engagement behaviors, J Commun Healthc. 2017 10:2,78-87, Available at: 10.1080/17538068.2017.1340541

34. Harrison R, Walton M, Chauhan A, Manias E, Chitkara $U$, Latanik $M$ et al. What is the role of cultural competence in ethnic minority consumer engagement? An analysis in community healthcare. 
Int J Equity Health. 2019 18: 191, Available at: https://doi.org/10.1186/s12939-019-1104-1

35. Perfetto EM, Oehrlein EM, Boutin M, Reid S, Gascho E. Value to whom? The patient voice in the value discussion. Value Health. 2017 Feb; 20(2):286-91.

36. Needham, J, Taylor, J, \& Nomikos D. Integrating Patient-Centred Research in the Canadian Cancer Trials Group. Curr Oncol 2021; 28(1), 630-639. https://doi.org/10.3390/curroncol28010062

37. Purificacion S, Brown E, Anne-Davis C, French J. Patient engagement in radiation therapy: The development of guidelines for current Canadian practices. Healthc Manage Forum 2016 Sep (Vol. 29, No. 5, pp. 187-195). Sage CA: Los Angeles, CA: SAGE Publications.

38. Bernstein E, Getchell L, Harwood L. Partnering with patients, families, and caregivers in nephrology nursing research. Nephrol Nurs J. 2019 May 1;46(3):3404.

39. Bar S, Grant K, Asuri S, Holms S. British Columbia Ministry of health patients as partners: a transformational approach. Healthc Manage Forum 2018 Mar (Vol. 31,
No. 2, pp. 51-56). Sage CA: Los Angeles, CA: SAGE Publications.

40. 40. Laurance J, Henderson S, Howitt PJ, Matar M, Al Kuwari H, Edgman-Levitan S, Darzi A. Patient engagement: four case studies that highlight the potential for improved health outcomes and reduced costs. Health Aff 2014 Sep 1;33(9):1627-34.

41. Thornton H, Edwards A, Elwyn G. Evolving the multiple roles of 'patients' in health-care research: reflections after involvement in a trial of shared decision-making. Health Expect 2003 Sep;6(3):189-97.

42. 42 Leonhardt KK. HRET patient safety leadership fellowship: the role of "community" in patient safety. Am J Med Qual 2010 May;25(3):192-6.

43. Smith AB, Chisolm S, Deal A, Spangler A, Quale DZ, Bangs R, Jones JM, Gore JL. Patient-centered prioritization of bladder cancer research. Cancer. 2018 Aug 1;124(15):3136-44.

44. Maslowski J. Patient participation: An emerging nursing issue Int J Hum Caring 2012;16(4):74-8.

45. Cropanzano R, Mitchell MS. Social exchange theory: An interdisciplinary review. J Manage. 2005 Dec;31 (6):874-900. 


\section{SEARCH STRATEGIES FOR SYSTEMATIC LITERATURE USING MEDICAL LITERATURE ANALYSIS AND RETRIEVAL SYSTEM (MEDLINE)}

\begin{tabular}{|l|l|}
\hline CODE & SEARCH TERMS \\
\hline S1 & $\begin{array}{l}\text { AB "patient-centred care" OR AB "patient-centered care" OR AB "patient-centred healthcare" OR } \\
\text { AB "patient-centered healthcare" OR AB "patient-centred medicine" OR AB "patient-centered } \\
\text { medicine" OR AB "person-centred care" OR AB "person centered care" OR AB "person-centred } \\
\text { practice" OR AB "person-centered practice" OR AB "person-centred healthcare" OR AB "person- } \\
\text { centered healthcare" }\end{array}$ \\
\hline S2 & $\begin{array}{l}\text { AB "client-centred practice" OR AB "client-centered practice" OR AB "consumer-centred care" OR } \\
\text { 'family-centered care" OR AB "patient and family centred care" OR AB "patient and family } \\
\text { centered care" OR AB "mutual healthcare" OR AB "customer-focused care" }\end{array}$ \\
\hline S3 & $\begin{array}{l}\text { (MH "Patient-Centered Care") } \\
\text { AB "patient centred care" OR AB "patient centered care" OR AB "patient centred healthcare" OR } \\
\text { medicine" OR AB "patient centred care" OR AB "person centered care" OR AB "person centred } \\
\text { practice" OR AB "person centred practice" OR AB "person centred healthcare" OR AB "person } \\
\text { centered healthcare" }\end{array}$ \\
\hline S5 & $\begin{array}{l}\text { AB "client centred practice" OR AB "client centered practice" OR AB "consumer centred care" OR } \\
\text { AB "personali?ed care" OR AB "family centred care" OR AB "family centered care" OR AB "patient } \\
\text { and family centred care" OR AB "patient and family centered care" OR AB "mutual health care" } \\
\text { OR AB "customer focused care" }\end{array}$ \\
\hline S6 & S1 OR S2 OR S3 OR S4 OR S5 \\
\hline S7 & AB Involvement OR AB participation OR AB meaningful OR AB genuine OR AB effective \\
\hline S12 & AB partnership OR AB collaboration OR AB co-creation OR AB cocreation OR AB "co creation" \\
\hline
\end{tabular}




\section{SEARCH STRATEGIES FOR SYSTEMATIC LITERATURE USING CUMULATIVE INDEX TO NURSING AND ALLIED HEALTH LITERATURE (CINAHL)}

\begin{tabular}{|l|l|}
\hline \multicolumn{1}{|l|}{ CODE } & SEARCH TERMS \\
\hline S1 & $\begin{array}{l}\text { AB "patient-centred care" OR AB "patient-centered care" OR AB "patient-centred healthcare" } \\
\text { OR AB "patient-centered healthcare" OR AB "patient-centred medicine" OR AB "patient- } \\
\text { centered medicine" OR AB "person-centred care" OR AB "person centered care" OR AB } \\
\text { "person-centred practice" OR AB "person-centered practice" OR AB "person-centred } \\
\text { healthcare" OR AB "person-centered healthcare" }\end{array}$ \\
\hline S2 & $\begin{array}{l}\text { AB "client-centred practice" OR AB "client-centered practice" OR AB "consumer-centred care" } \\
\text { OR AB "consumer-centred care" OR AB "personali?ed care" OR AB "family-centred care" OR AB } \\
\text { 'family-centered care" OR AB "patient and family centred care" OR AB "patient and family } \\
\text { centered care" OR AB "mutual healthcare" OR AB "customer-focused care" }\end{array}$ \\
\hline S3 & (MH "Patient-Centered Care") or (MH 'person-centred care') \\
\hline S4 & $\begin{array}{l}\text { AB "patient centred care" OR AB "patient centered care" OR AB "patient centred healthcare" } \\
\text { OR AB "patient centered healthcare" OR AB "patient centred medicine" OR AB "patient } \\
\text { Centered medicine" OR AB "patient centred care" OR AB "person centered care" OR AB } \\
\text { "person centred practice" OR AB "person centred practice" OR AB "person centred healthcare" } \\
\text { OR AB "person centered healthcare" }\end{array}$ \\
\hline S5 & $\begin{array}{l}\text { AB "client centred practice" OR AB "client centered practice" OR AB "consumer centred care" } \\
\text { OR AB "personali?ed care" OR AB "family centred care" OR AB "family centered care" OR AB } \\
\text { "patient and family centred care" OR AB "patient and family centered care" OR AB "mutual } \\
\text { health care" OR AB "customer focused care }\end{array}$ \\
\hline S7 & S1 OR S2 OR S3 OR S4 OR S5 \\
\hline S6 & AB Involvement OR AB participation OR AB meaningful OR AB genuine OR AB effective \\
\hline S6 AND S7 AND S8 AND S9
\end{tabular}




\section{SEARCH STRATEGIES FOR SYSTEMATIC LITERATURE USING EMBASE}

\begin{tabular}{|c|c|}
\hline CODE & SEARCH TERMS \\
\hline S1 & $\begin{array}{l}A B \text { "patient-centred care" OR AB "patient-centered care" OR AB "patient-centred healthcare" OR } \\
A B \text { "patient-centered healthcare" OR AB "patient-centred medicine" OR AB "patient-centered } \\
\text { medicine" OR AB "person-centred care" OR AB "person centered care" OR AB "person-centred } \\
\text { practice" OR AB "person-centered practice" OR AB "person-centred healthcare" OR AB "person- } \\
\text { centered healthcare" }\end{array}$ \\
\hline S2 & $\begin{array}{l}\text { AB "client-centred practice" OR AB "client-centered practice" OR AB "consumer-centred care" OR } \\
A B \text { "consumer-centred care" OR AB "personaliẹed care" OR AB "family-centred care" OR AB } \\
\text { 'family-centered care" OR AB "patient and family centred care" OR AB "patient and family } \\
\text { centered care" OR AB "mutual healthcare" OR AB "customer-focused care" }\end{array}$ \\
\hline S3 & (MH "Patient-Centered Care") \\
\hline S4 & $\begin{array}{l}A B \text { "patient centred care" OR AB "patient centered care" OR AB "patient centred healthcare" OR } \\
A B \text { "patient centered healthcare" OR AB "patient centred medicine" OR AB "patient centered } \\
\text { medicine" OR AB "patient centred care" OR AB "person centered care" OR AB "person centred } \\
\text { practice" OR AB "person centred practice" OR AB "person centred healthcare" OR AB "person } \\
\text { centered healthcare" }\end{array}$ \\
\hline S5 & $\begin{array}{l}A B \text { "client centred practice" OR AB "client centered practice" OR AB "consumer centred care" OR } \\
A B \text { "personalięed care" OR AB "family centred care" OR AB "family centered care" OR AB "patient } \\
\text { and family centred care" OR AB "patient and family centered care" OR AB "mutual health care" } \\
\text { OR AB "customer focused care" }\end{array}$ \\
\hline S6 & S1 OR S2 OR S3 OR S4 OR S5 \\
\hline S7 & $A B$ Involvement $O R A B$ participation $O R A B$ meaningful $O R A B$ genuine $O R A B$ effective \\
\hline S10 & AB partnership OR AB collaboration OR AB co-creation OR AB cocreation OR AB "co creation" \\
\hline S11 & AB "Patient engagement" OR "Consumer engagement" OR "Community engagement" \\
\hline S12 & S6 AND S7 AND S10 AND S17 (old codes) \\
\hline
\end{tabular}




\section{SEARCH STRATEGIES FOR SYSTEMATIC LITERATURE USING PSYCHINFO}

\begin{tabular}{|c|c|}
\hline CODE & SEARCH TERMS \\
\hline S1 & $\begin{array}{l}A B \text { "patient-centred care" OR AB "patient-centered care" OR AB "patient-centred healthcare" OR } \\
A B \text { "patient-centered healthcare" OR AB "patient-centred medicine" OR AB "patient-centered } \\
\text { medicine" OR AB "person-centred care" OR AB "person centered care" OR AB "person-centred } \\
\text { practice" OR AB "person-centered practice" OR AB "person-centred healthcare" OR AB "person- } \\
\text { centered healthcare" }\end{array}$ \\
\hline S2 & $\begin{array}{l}A B \text { "client-centred practice" OR AB "client-centered practice" OR AB "consumer-centred care" OR } \\
A B \text { "consumer-centred care" OR AB "personalie ed care" OR AB "family-centred care" OR AB } \\
\text { 'family-centered care" OR AB "patient and family centred care" OR AB "patient and family } \\
\text { centered care" OR AB "mutual healthcare" OR AB "customer-focused care" }\end{array}$ \\
\hline S3 & (MH "Patient-Centered Care") \\
\hline S4 & $\begin{array}{l}A B \text { "patient centred care" OR AB "patient centered care" OR AB "patient centred healthcare" OR } \\
A B \text { "patient centered healthcare" OR AB "patient centred medicine" OR AB "patient centered } \\
\text { medicine" OR AB "patient centred care" OR AB "person centered care" OR AB "person centred } \\
\text { practice" OR AB "person centred practice" OR AB "person centred healthcare" OR AB "person } \\
\text { centered healthcare" }\end{array}$ \\
\hline S5 & $\begin{array}{l}A B \text { "client centred practice" OR AB "client centered practice" OR AB "consumer centred care" OR } \\
A B \text { "personaliẹed care" OR AB "family centred care" OR AB "family centered care" OR AB "patient } \\
\text { and family centred care" OR AB "patient and family centered care" OR AB "mutual health care" } \\
\text { OR AB "customer focused care" }\end{array}$ \\
\hline S6 & S1 OR S2 OR S3 OR S4 OR S5 \\
\hline S7 & $A B$ Involvement $O R A B$ participation $O R A B$ meaningful $O R A B$ genuine $O R$ AB effective \\
\hline S10 & AB partnership OR AB collaboration OR AB co-creation OR AB cocreation OR AB "co creation" \\
\hline S11 & AB "Patient engagement" OR "Consumer engagement" OR "Community engagement" \\
\hline S12 & S6 AND S7 AND S10 AND S11 \\
\hline
\end{tabular}




\begin{tabular}{|c|c|c|c|c|c|c|c|c|c|c|c|}
\hline & $\begin{array}{l}\text { Needman } \\
\text { et al (2021) }\end{array}$ & $\begin{array}{l}\text { Westlake } \\
\text { et al [25] }\end{array}$ & $\begin{array}{l}\text { Majid \& } \\
\text { Gagliardi } \\
\text { [26] }\end{array}$ & $\begin{array}{l}\text { Bernste } \\
\text { in et al } \\
\text { [38] }\end{array}$ & $\begin{array}{l}\text { Bar et } \\
\text { al [39] }\end{array}$ & $\begin{array}{l}\text { Pinsoncult } \\
\text { et al [27] }\end{array}$ & $\begin{array}{l}\text { Smith } \\
\text { et al } \\
\text { [43] }\end{array}$ & $\begin{array}{l}\text { Warren } \\
\text { et al } \\
\text { [28] }\end{array}$ & $\begin{array}{l}\text { Car } \\
\text { man } \\
\text { et al } \\
\text { [7] }\end{array}$ & $\begin{array}{l}\text { Pushp } \\
\text { arj et } \\
\text { al [27] }\end{array}$ & $\begin{array}{l}\text { Phillips } \\
\text { et al } \\
\text { [24] }\end{array}$ \\
\hline \multicolumn{12}{|l|}{$\begin{array}{l}\text { Screening questions } \\
\text { (for all types) }\end{array}$} \\
\hline $\begin{array}{l}\text { S1. Are there clear } \\
\text { research questions? }\end{array}$ & $x$ & $\checkmark$ & $\checkmark$ & $x$ & $x$ & $\checkmark$ & $x$ & $\checkmark$ & $x$ & $x$ & $\checkmark$ \\
\hline $\begin{array}{l}\text { S2. Do the collected } \\
\text { data a low to } \\
\text { address the research } \\
\text { questions? }\end{array}$ & $x$ & $\checkmark$ & $\checkmark$ & $x$ & $x$ & $\checkmark$ & $x$ & $\checkmark$ & $x$ & $x$ & $\checkmark$ \\
\hline \multicolumn{12}{|l|}{ Qualitative } \\
\hline $\begin{array}{l}1.1 \text { Is the qualitative } \\
\text { approach } \\
\text { appropriate to } \\
\text { answer the question? }\end{array}$ & $x$ & $\checkmark$ & $\checkmark$ & & & $\checkmark$ & & $x$ & & & $\checkmark$ \\
\hline $\begin{array}{l}1.2 \text { Are the } \\
\text { qualitative data } \\
\text { collection methods } \\
\text { adequate to address } \\
\text { the research } \\
\text { questions? }\end{array}$ & $x$ & $\checkmark$ & $\checkmark$ & & & $\checkmark$ & & $x$ & & & $\checkmark$ \\
\hline $\begin{array}{l}1.3 \text { Are the findings } \\
\text { adequately derived } \\
\text { from the data? }\end{array}$ & $x$ & $\checkmark$ & $\checkmark$ & & & $\checkmark$ & & $x$ & & & $\checkmark$ \\
\hline $\begin{array}{l}1.4 \text { Is the } \\
\text { interpretation of the } \\
\text { results sufficiently } \\
\text { substantiated by } \\
\text { data? }\end{array}$ & $x$ & $\checkmark$ & $\checkmark$ & & & $\checkmark$ & & $x$ & & & $\checkmark$ \\
\hline $\begin{array}{l}1.5 \text { Is there } \\
\text { coherence between } \\
\text { qualitative data } \\
\text { sources, collection, } \\
\text { analysis, and } \\
\text { interpretation? }\end{array}$ & $x$ & $\checkmark$ & $\checkmark$ & & & $\checkmark$ & & $x$ & & & $\checkmark$ \\
\hline \multicolumn{12}{|l|}{$\begin{array}{l}\text { Quantitative } \\
\text { randomised control } \\
\text { trial }\end{array}$} \\
\hline \multicolumn{12}{|l|}{$\begin{array}{l}2.1 \text { Is randomistaion } \\
\text { appropriately } \\
\text { performed }\end{array}$} \\
\hline \multicolumn{12}{|l|}{$\begin{array}{l}\text { 2.2. Are the groups } \\
\text { comparable at } \\
\text { baseline? }\end{array}$} \\
\hline \multicolumn{12}{|l|}{$\begin{array}{l}2.3 \text { Are there } \\
\text { compete data } \\
\text { outcome? }\end{array}$} \\
\hline \multicolumn{12}{|l|}{$\begin{array}{l}2.4 \text { Are outcomes } \\
\text { assessors blind to the } \\
\text { intervention } \\
\text { provided? }\end{array}$} \\
\hline \multicolumn{12}{|l|}{$\begin{array}{l}2.5 \text { Did the } \\
\text { participants adhere } \\
\text { to the assigned } \\
\text { intervention? }\end{array}$} \\
\hline \multicolumn{12}{|l|}{$\begin{array}{l}\text { Quantitative non- } \\
\text { randomised }\end{array}$} \\
\hline \multicolumn{12}{|l|}{$\begin{array}{l}3.1 \text { Are the } \\
\text { participants } \\
\text { representative of the } \\
\text { target population? }\end{array}$} \\
\hline $\begin{array}{l}3.2 \text { Are } \\
\text { measurements } \\
\text { appropriate }\end{array}$ & & & & & & & & & & & \\
\hline
\end{tabular}




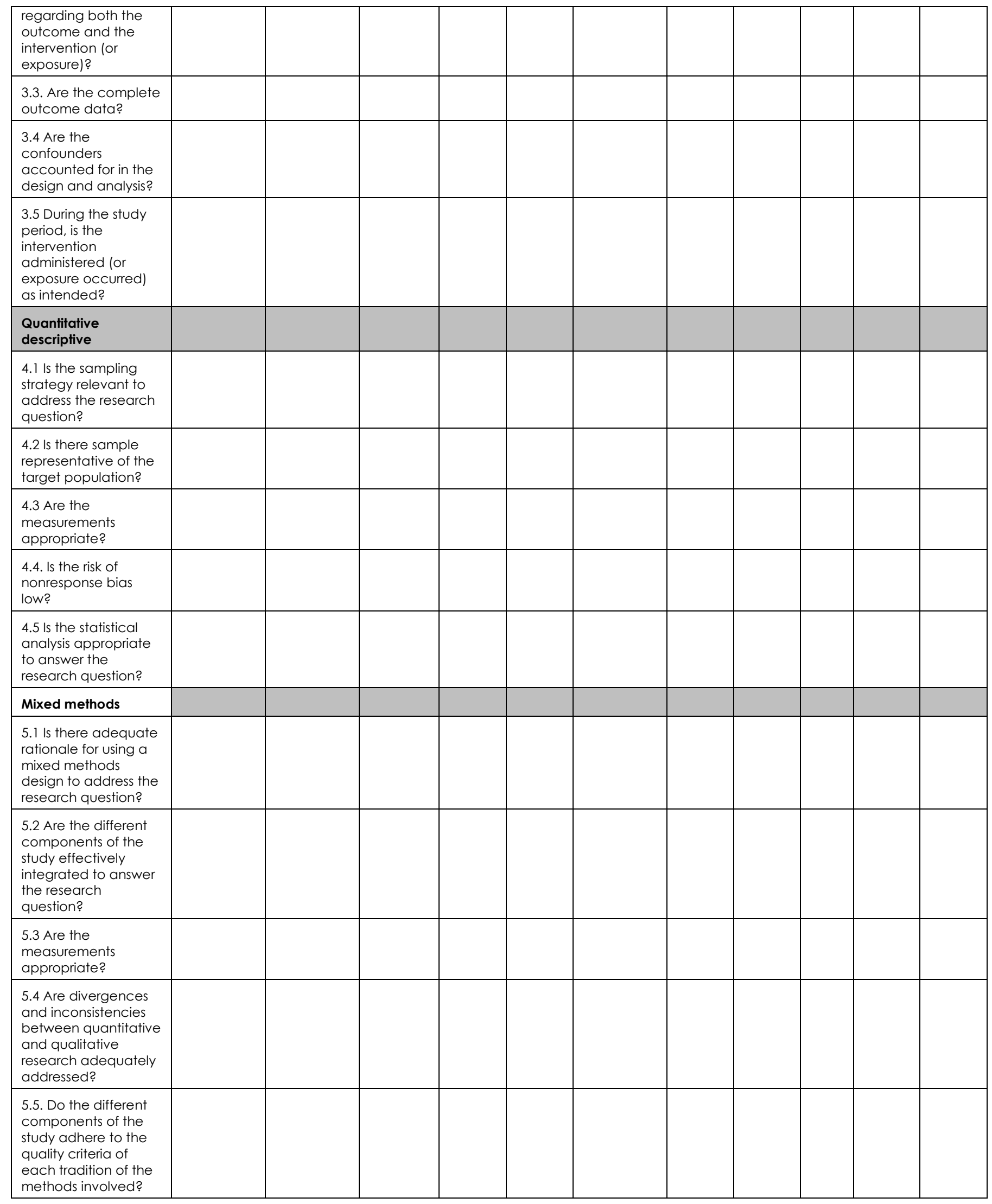




\begin{tabular}{|c|c|c|c|c|c|c|c|c|c|c|c|c|}
\hline & $\begin{array}{c}\text { Newell \& } \\
\text { Jordon [29] }\end{array}$ & $\begin{array}{l}\text { Kane } \\
\text { et al. } \\
{[30]}\end{array}$ & $\begin{array}{l}\text { Pe } \\
\text { rife } \\
\text { tio } \\
\text { et } \\
\text { al } \\
{[35}\end{array}$ & $\begin{array}{l}\text { DeCa } \\
\text { mp et } \\
\text { al. [31] }\end{array}$ & $\begin{array}{l}\text { Sapir } \\
\text { et al } \\
\text { [32] }\end{array}$ & $\begin{array}{l}\text { Purificaci } \\
\text { on ef al } \\
\text { [38] }\end{array}$ & $\begin{array}{l}\text { Laur } \\
\text { anc } \\
\text { e et } \\
\text { al. } \\
{[40]}\end{array}$ & $\begin{array}{c}\text { Thornton ef } \\
\text { al [41] }\end{array}$ & $\begin{array}{l}\text { Leonh } \\
\text { ard } \\
{[42]}\end{array}$ & $\begin{array}{l}\text { Maslows } \\
\text { ki [44] }\end{array}$ & $\begin{array}{l}\text { Sloan } \\
\& \\
\text { Knowl } \\
\text { es [33] }\end{array}$ & $\begin{array}{l}\text { Harri } \\
\text { son } \\
\text { et al } \\
\text { [34] }\end{array}$ \\
\hline \multicolumn{13}{|l|}{$\begin{array}{l}\text { Screening questions } \\
\text { (for all types) }\end{array}$} \\
\hline $\begin{array}{l}\text { S1. Are there clear } \\
\text { research questions? }\end{array}$ & $\checkmark$ & $\checkmark$ & $\checkmark$ & $\checkmark$ & $\checkmark$ & $\checkmark$ & $x$ & $x$ & $x$ & $x$ & $\checkmark$ & $\checkmark$ \\
\hline $\begin{array}{l}\text { S2. Do the collected } \\
\text { data a low to address } \\
\text { the research } \\
\text { questions? }\end{array}$ & $\checkmark$ & $\checkmark$ & $\checkmark$ & $\checkmark$ & $\checkmark$ & $x$ & $x$ & $x$ & $x$ & $x$ & $\checkmark$ & $\checkmark$ \\
\hline \multicolumn{13}{|l|}{ Qualitative } \\
\hline $\begin{array}{l}1.1 \text { Is the qualitative } \\
\text { approach appropriate } \\
\text { to answer the } \\
\text { question? }\end{array}$ & $x$ & $\checkmark$ & $\checkmark$ & $\checkmark$ & & $\checkmark$ & & & & & $\checkmark$ & $\checkmark$ \\
\hline $\begin{array}{l}1.2 \text { Are the qualitative } \\
\text { data collection } \\
\text { methods adequate to } \\
\text { address the research } \\
\text { questions? }\end{array}$ & $x$ & $\checkmark$ & $\checkmark$ & $\checkmark$ & & $x$ & & & & & $\checkmark$ & $\checkmark$ \\
\hline $\begin{array}{l}1.3 \text { Are the findings } \\
\text { adequately derived } \\
\text { from the data? }\end{array}$ & $x$ & $\checkmark$ & $\checkmark$ & $\checkmark$ & & $\checkmark$ & & & & & $\checkmark$ & $\checkmark$ \\
\hline $\begin{array}{l}1.4 \text { Is the interpretation } \\
\text { of the results sufficiently } \\
\text { substantiated by data? }\end{array}$ & $x$ & $\checkmark$ & $\checkmark$ & $\checkmark$ & & $\checkmark$ & & & & & $\checkmark$ & $\checkmark$ \\
\hline $\begin{array}{l}1.5 \text { Is there coherence } \\
\text { between qualitative } \\
\text { data sources, } \\
\text { collection, analysis, } \\
\text { and interoretation? }\end{array}$ & $x$ & $\checkmark$ & $\checkmark$ & $\checkmark$ & & $\checkmark$ & & & & & $\checkmark$ & $\checkmark$ \\
\hline \multicolumn{13}{|l|}{$\begin{array}{l}\text { Quantitative } \\
\text { randomised control } \\
\text { trial }\end{array}$} \\
\hline \multicolumn{13}{|l|}{$\begin{array}{l}2.1 \text { Is randomistaion } \\
\text { appropriately } \\
\text { performed }\end{array}$} \\
\hline \multicolumn{13}{|l|}{$\begin{array}{l}\text { 2.2. Are the groups } \\
\text { comparable at } \\
\text { baseline? }\end{array}$} \\
\hline \multicolumn{13}{|l|}{$\begin{array}{l}2.3 \text { Are there compete } \\
\text { data outcome? }\end{array}$} \\
\hline \multicolumn{13}{|l|}{$\begin{array}{l}2.4 \text { Are outcomes } \\
\text { assessors blind to the } \\
\text { intervention provided? }\end{array}$} \\
\hline \multicolumn{13}{|l|}{$\begin{array}{l}2.5 \text { Did the participants } \\
\text { adhere to the assigned } \\
\text { intervention? }\end{array}$} \\
\hline \multicolumn{13}{|l|}{$\begin{array}{l}\text { Quantitative non- } \\
\text { randomised }\end{array}$} \\
\hline \multicolumn{13}{|l|}{$\begin{array}{l}3.1 \text { Are the participants } \\
\text { representative of the } \\
\text { target population? }\end{array}$} \\
\hline \multicolumn{13}{|l|}{$\begin{array}{l}3.2 \text { Are measurements } \\
\text { appropriate regarding } \\
\text { both the outcome and } \\
\text { the intervention (or } \\
\text { exposure)? }\end{array}$} \\
\hline \multicolumn{13}{|l|}{$\begin{array}{l}\text { 3.3. Are the complete } \\
\text { outcome data? }\end{array}$} \\
\hline \multicolumn{13}{|l|}{$\begin{array}{l}3.4 \text { Are the } \\
\text { confounders } \\
\text { accounted for in the } \\
\text { design and analysis? }\end{array}$} \\
\hline \multicolumn{13}{|l|}{$\begin{array}{l}3.5 \text { During the study } \\
\text { period, is the } \\
\text { intervention } \\
\text { administered (or } \\
\text { exposure occurred) as } \\
\text { intended? }\end{array}$} \\
\hline \multicolumn{13}{|l|}{$\begin{array}{l}\text { Quantitative } \\
\text { descriptive }\end{array}$} \\
\hline $\begin{array}{l}4.1 \text { is the sampling } \\
\text { strategy relevant to } \\
\text { address the research } \\
\text { question? }\end{array}$ & & $\checkmark$ & & & $\checkmark$ & & & & & & & \\
\hline
\end{tabular}




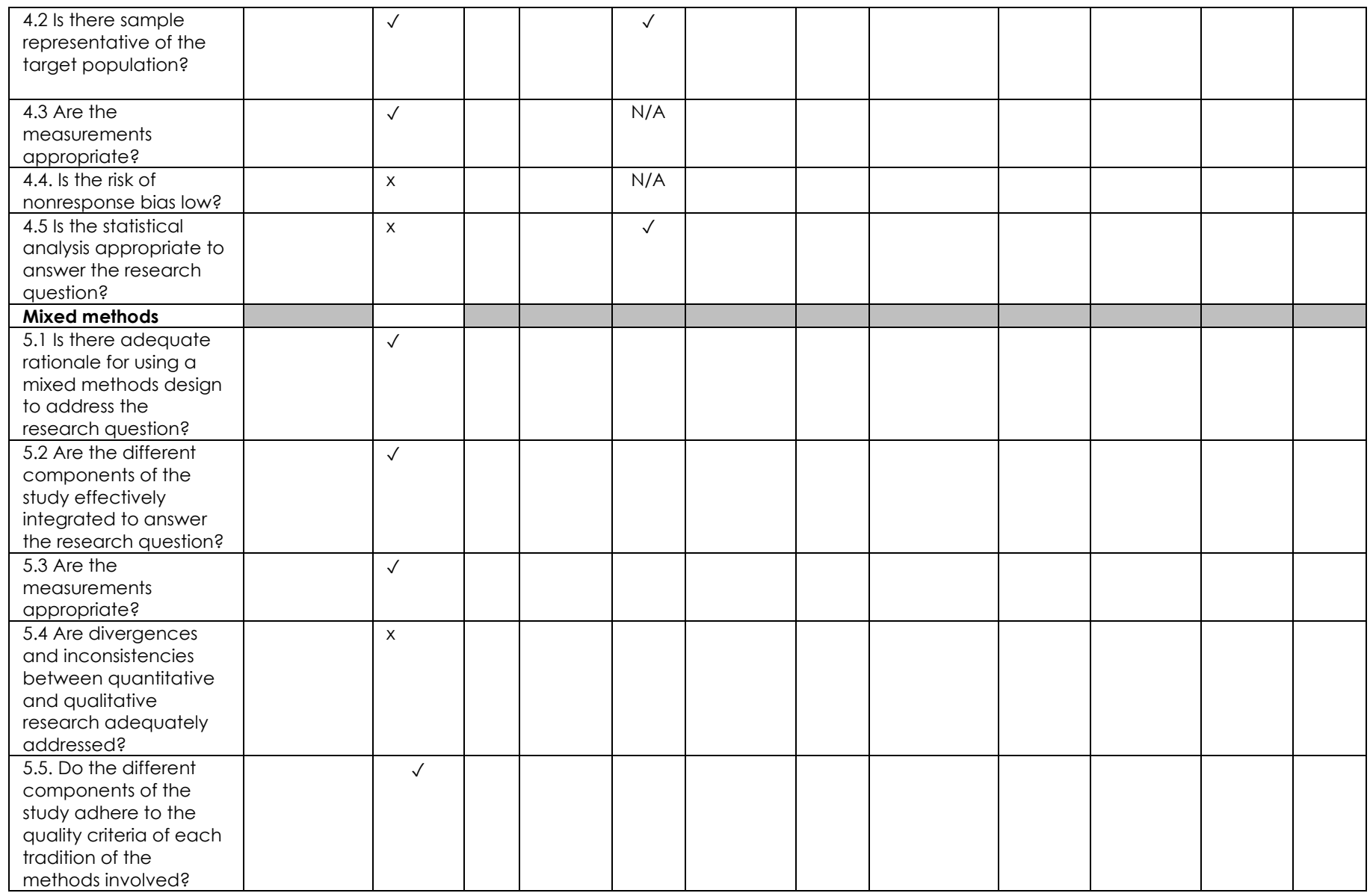

